\title{
The importance of weight for height in prediction of metabolic syndrome in obese children and adolescents: impact of gender and puberty
}

\author{
Obez çocuk ve adolesanlarda metabolik sendrom öngörüsünde boya uyan ağırlığın \\ önemi; cinsiyet ve pubertenin etkisi
}

\author{
Bayram Özhan*, Betül Ersoy**
}

*Pamukkale Üniversitesi Tıp Fakültesi, Çocuk Sağlığı ve Hastalıkları BD,Denizli

**Celal Bayar Üniversitesi Tıp Fakültesi, Çocuk Sağığı ve Hastalıkları BD,Manisa

\begin{abstract}
Purpose:To determine the role of anthropometric indices such as waist circumference, waist-to-hip ratio, waistheight ratio, and weight for height in predicting metabolic syndrome in obese children and adolescents.

Materials and methods: A total of 291 obese children and adolescents aged 6-16 years were included in this study. Anthropometric and biochemical parameters were evaluated. Metabolic syndrome was defined according to the International Diabetes Federation criteria.

Results:The prevalence of metabolic syndrome was $22.3 \%$ and significantly higher in pubertal obese group than in pre-pubertal ones $(p=0.004)$. Higher waist circumference and weight for height were found in obese children and adolescents with metabolic syndrome $(p<0.05)$. Significantly higher weight for height was found in obese girls with metabolic syndrome but the difference was not significant for obese boys. Multi-variable logistic regression analysis revealed that weight for height was the most important predictor of metabolic syndrome in obese children and adolescents except obese boys $(p<0.05)$.

Conclusion: Weight for height may be a better marker predictor of metabolic syndrome in obese children and adolescents. The cut-off point of weight for height of $136.5 \%$ for all obese children, pubertal obese children, and obese girls, $139.5 \%$ for pre-pubertal obese children was proposed to predict for metabolic syndrome. Anthropometric parameters, particularly weight for height, must be evaluated in all obese children.
\end{abstract}

Pam Med J 2017;(1):23-32

Key words: Weight for height, obesity, children, anthropometric indices, waist circumference.

\section{Özet}

Amaç:Obez çocuklar ve ergenlerde, metabolik sendrom tanısının öngörülmesinde bel çevresi, bel-kalça oranı, bel-boy oranı, ve boya uyan ağırlık gibi antropometrik endekslerin rolünü belirlemek.

Gereç ve yöntem: Bu çalışmaya 6-16 yaş arasındaki toplam 291 obez çocuk ve ergen dahil edildi. Antropometrik ve biyokimyasal parametreler değerlendirildi. Metabolik sendrom tanısı, Uluslararası Diyabet Federasyonu kriterlerine göre tanımlandı.

Bulgular: Metabolik sendrom prevalansı \% 22,3 (65) idi ve pubertal obez grupta prebupertal gruba göre anlamlı derecede yüksekti $(p=0.004)$. Obez çocuklarda ve metabolik sendromlu ergenlerde yüksek bel çevresi ve bel-boy oranı saptandı ( $p$ <.05). Metabolik sendrom olan obez kızlarda anlamlı olarak yüksek bel-boy oranı bulundu, ancak obez erkeklerdeki fark anlamlı değildi. Çok değişkenli lojistik regresyon analizinde, obez çocuk ve ergenlerde boya uyan ağırlık metabolik sendromun belirteci olarak kabul edilebilir saptandı $(p<0.05)$.

Sonuç: Obez çocuklar ve ergenlerde, boya uyan ağırlık metabolik sendrom öngörüsünde iyi bir belirteç olabilir. Tüm obez çocuklar, ergenlik çağındaki obez çocuklar ve obez kızlar için boya uyan ağırlık için kesme noktası \% 136.5, pre-pubertal obez çocuklar için \% 139.5, metabolik sendromu öngörmek için kullanılabilir. Antropometrik parametreler, özellikle boya uyan ağırlık, tüm obez çocuklarda değerlendirilmelidir.

Pam Tıp Derg 2017;(1):23-32

Anahtar sözcükler: Boya uyan ağırlık, obezite, çocuklar, antropometrik endeksler, bel çevresi.

Bayram Özhan

Yazışma Adresi: Pamukkale Üniversitesi Tıp Fakültesi, Çocuk Sağlığı ve Hastalıkları BD, Denizli.

e-mail: bayramozhan@yahoo.com] 


\section{Introduction}

The clustering of risk factors, which is associated with insulin resistance, is called the metabolic syndrome (MetS), also known as syndrome $X[1]$. An increasing prevalence of MetS associated with obesity is threatening public health around the world in both childhood and adulthood. There are still no universally accepted diagnostic criteria for MetS in childhood [2]. Additionally, there are no population-based studies to develop cut-off values for MetS assessment in the pediatric population [3]. Therefore, the prevalence of MetS varies depending on the criteria used in different definitions, as well as different childhood cut-off values in childhood [2-4]. Furthermore, prevalence of MetS may change according to pubertal status and gender. Recently, it has been reported that there are racial and gender differences in predicting insulin resistance with MetS among adolescents [5]. During puberty, insulin resistance, one of the important MetS components, transiently increases physiologically [3].

Anthropometric indices such as waist circumference (WC) and waist-to-hip ratio (WHR), appear to be more strongly associated with metabolic risk factors in adults [7]. Similarly, in some studies, it has been reported that WC and WHR were better indicators for cardiometabolic risk in obese children and adolescents as well $[8,9]$. Recently, a new index called the waistheight ratio (WHtR) has been proposed for a significant predictor of the metabolic syndrome in obese youth [10]. On the other hand, it was demonstrated that weight for height $(\mathrm{W} / \mathrm{H})$ is a reliable way to describe the nutritional status of children, particularly well-nourished population. $\mathrm{W} / \mathrm{H}$ of more than $120 \%$ of the standard weight indicates obesity [11]. We thought that $\mathrm{W} / \mathrm{H}$ may play a role in predicting MetS in obese children. Anthropometric markers for MetS are simple and cheap, and may be a good predictors. However, further studies are still necessary to ascertain the clinical significance of anthropometry for metabolic syndrome.

In the present study, we estimated the prevalence of MetS among obese children and adolescents according to International Diabetes Federation (IDF) criteria [12]. We aimed to assess the role of anthropometric indices such as WC, WHR, WHtR, and $\mathrm{W} / \mathrm{H}$ in prediction of MetS in obese children and adolescents. In addition, we aimed to describe the effects of gender differences and pubertal status on these anthropometric indices.

\section{Subjects and Methods}

\section{Study Population}

A total of 291 obese children and adolescents (160 girls and 131 boys of age range: 6-16 years, mean age: $11.84 \pm 2.62$ years) who were referred to the Department of Pediatric Endocrinology at Celal Bayar University between January 2010 and December 2010 were included in this study. After the overnight fasting, venous blood samples were drawn to assess glucose, insulin, glycated hemoglobin (HbA1c), total cholesterol (TC), triglyceride (TG), and high-density lipoprotein-cholesterol (HDL-C). In all subjects, thyroid function tests (TFT), diurnal cortisol levels and basal adrenocorticotropic hormone (ACTH) levels were assessed to exclude hypothyroidism and hypercortisolism. The presence of major disease and/or genetic and endocrinological disease causing secondary obesity and the use of any medication were accepted as exclusion criteria. All participants underwent a thorough physical examination by a pediatric endocrinologist. The pubertal stage was determined according to Tanner criteria. This study was approved by our Institution's Scientific Ethics Committee for Human Studies of the University of Medical Faculty, and written informed consent was obtained from the parents of all subjects at the beginning of the study.

\section{Anthropometric Measurements}

Weight was measured to the nearest $0.5 \mathrm{~kg}$ using a balance beam scale and height was measured to the nearest $0.1 \mathrm{~cm}$ with a manual height board. BMI was calculated according to the formula body weight $(\mathrm{kg}) /$ height square $\left(\mathrm{m}^{2}\right)$. Comparison of weight, height and BMI among children requires the use of standard deviation scores (SDS). SDS for height and weight were calculated based on national growth charts [13]. Waist circumference (WC) was measured at the midpoint between the inferior border of the rib cage and superior aspect of the iliac crest at the end of gentle expiration. Hip circumference was measured at the widest level over the greater trochanter, and $\mathrm{WHpR}$ was calculated by dividing waist circumference $(\mathrm{cm})$ by hip 
circumference $(\mathrm{cm})$. WHtR was calculated by WC $(\mathrm{cm}) /$ height $(\mathrm{cm})$. W/H is defined as actual weight divided by the standard median weight for subject's sex and height.

Sitting blood pressure was measured with a standard mercury sphygmomanometer after the subject had rested quietly for at least 10 min. Consensus guidelines define hypertension during childhood as blood pressure that is, on three different visits, measured at or higher than the 95th percentile for age, sex, and height [14].

\section{Definitions}

Obesity was defined as BMI $\geq$ 95th percentile for age and gender based on published standards (15). Central obesity was defined as $W C \geq 90$ th percentile for age according previously published data [16]. The definition of IDF for diagnosis of the metabolic syndrome was used [12].The IDF criteria for MS in adolescents aged 10-16 years include abdominal or central obesity (90th percentile of waist circumference or adult cut-off if lower) plus at least 2 of the following features: fasting plasma triglyceride of $\geq 150 \mathrm{mg} / \mathrm{dL}$, high-density lipoprotein cholesterol (HDL-C) of $<40 \mathrm{mg} / \mathrm{dL}$, systolic blood pressure of $\geq 130 \mathrm{mmHg}$ and/or diastolic blood pressure of $\geq 85 \mathrm{mmHg}$, fasting plasma glucose of $\geq 100 \mathrm{mg} / \mathrm{dL}$, or known type 2 diabetes mellitus [10]. This definition was used to diagnose MetS because these are the established criteria for children aged 10-16 years, and the age group of the majority of our patients. High TG ( $\geq 95$ th percentile for age and sex) and low HDL-C levels (<5th percentile for age and sex) are used for children under 10 years old.

\section{Biochemical Assessments}

Venous blood samples were obtained after 10 hours fasting at 08 a.m. to 10:00 a.m. Serum glucose, TG, AST, ALT, HDL-C, and Total- $C$ levels were assessed by original commercial reagents (Beckman Coulter Ireland Inc., Mervue, Galway, Ireland) on analyzer (UniCel DxC 800 Synchron Clinical System, Fullerton, CA, USA). Low density cholesterol (LDL-C) concentrations were obtained by using the Friedwald ve Frederickson formula (17). Serum insulin concentrations were analyzed by chemiluminescent immunometric assay method on analyzer (Siemens IMMULITE 2000, Siemens Medical Solutions Diagnostics
Limited Llanberis, United Kingdom) with original reagents. Serum glucose and insulin were used for the calculation of homeostasis model assessment $(\mathrm{HOMA}-\mathrm{IR})=$ fast insulin $(\mathrm{mlU} / \mathrm{mL})$ $\times$ fast glucose $(\mathrm{mg} / \mathrm{dL}) / 22.5](\mathrm{mg} / \mathrm{dL}=\mathrm{mmol} / \mathrm{L}$ $\times$ 18.182) [18].

\section{Statistical Analysis}

All data are expressed as means \pm SD and $p<0.05$ was considered statistically significant. The normality assumption for continuous variables was tested using the KolmogorovSmirnov test. Differences between the two groups were evaluated by Student $t$ test. Categorical variables were assessed using the $\mathrm{x} 2$ test. Multivariable logistic regression was used to assess the association of anthropometric parameters with the presence of MetS. Adjusted OR and their corresponding $95 \% \mathrm{Cl}$ were calculated. The prevalence of metabolic risk factors and metabolic syndrome by anthropometric parameters was calculated, followed by the sensitivity (ability to detect adolescents with metabolic syndrome) and specificity (ability to detect adolescents without metabolic syndrome) of the thresholds. Then, positive predictive values (PPVs; proportion of obese adolescents and children with metabolic syndrome) and negative predictive values (NPVs; proportion of obese adolescents and children without metabolic syndrome) were calculated. Higher values for sensitivity, specificity, PPVs, and PPVs indicate more effective thresholds. ROC curves were used to determine optimal thresholds to detect metabolic syndrome. The analysis used presence of metabolic syndrome as the criterion and weight for height as the continuous test variable. The analysis evaluated the sensitivity and specificity of each possible weight for height to detect metabolic syndrome. Two methods for identifying optimal cut-off points using sensitivity, specificity and the ROC curve are commonly used. The method we used to choose the best cut-off point for balancing the sensitivity and specificity of a test is the point on the curve closest to the $(0,1)$ point. In this method, optimal sensitivity and specificity are defined as those yielding the minimal value for $(1-\text { sensitivity })^{2}+(1-\text { specificity })^{2}$. The cutoff point corresponding to these sensitivity and specificity values is the one closest to the $(0$, 1) point and is taken to be the cut-off point that best differentiates between people with disease and those without disease. 


\section{Results}

Mean age of obese children with and without MetS was $11.78 \pm 2.76$ and $12.51 \pm 2.42$ years, respectively. Difference was not statistically significant $(p=0.058)$. Of these obese children and adolescents, 55.0\% ( $n=160)$ were girls, and $45.0 \%$ ( $n=131$ ) were boys. Of the total, $33.3 \%(n=97)$ were pre-pubertal and $66.6 \%$ $(n=194)$ were pubertal. The prevalence of MetS was $22.3 \%$ (65) in all participants (Figure 1). The anthropometric characteristics of obese children with and without MetS are shown in Table 1. Assessing all participants, WC and weight for height in obese with MetS were significantly higher compared to obese without MetS ( $p=0.022)$. BMI SDS, WHR, and WHtR did not differ significantly between the two groups $(p>0.05)$.
Evaluating according to pubertal status, the prevalence of MetS was $27.3 \%$ (53) in pubertal obese children whereas it was $12.3 \%$ (12) in pre-pubertal obese children (Figure 1). The difference was significant $(p=0.004)$. Mean age was not a significant difference between obese children with and without MetS in both prepubertal and pubertal obese children $(p>0.05)$. Pre-pubertal obese children with MetS had significantly higher WHtR compared to obese children without MetS $(p=0.008)$. Significantly higher weight for height was found in both pubertal and pre-pubertal obese children with MetS than those without MetS $(p=0.005, p=0.01$, respectively) (Table 2).

Table 1. Anthropometric characteristics in obese children with and without MetS.

\begin{tabular}{lccc}
\hline Anthropometric characteristics & $\begin{array}{c}\text { Obese without MetS } \\
\text { n: } \mathbf{2 2 6}\end{array}$ & $\begin{array}{c}\text { Obese with MetS } \\
\text { n: } \mathbf{6 5}\end{array}$ & $\boldsymbol{P}$ \\
\hline Age (years) & $11.78 \pm 2.76$ & $12.51 \pm 2.42$ & 0.058 \\
Height SDS & $0.65 \pm 1.15$ & $153.73 \pm 11.80$ & 0.130 \\
Weight SDS & $3.41 \pm 1.47$ & $3.88 \pm 2.03$ & 0.377 \\
BMI SDS & $3.21 \pm 1.35$ & $3.36 \pm 1.31$ & 0.063 \\
W/H (\%) & $142.04 \pm 16.99$ & $151.86 \pm 18.75$ & $<\mathbf{0 . 0 1}$ \\
WC (cm) & $91.67 \pm 13.19$ & $95.63 \pm 12.59$ & $\mathbf{0 . 0 2 2}$ \\
WHR & $0.93 \pm 0.06$ & $0.93 \pm 0.067$ & 0.956 \\
WHtR & $0.60 \pm 0.06$ & $0.62 \pm 0.06$ & 0.069 \\
\hline
\end{tabular}

SDS: Standard Deviation Scores BMI: Body mass index, WC: Waist circumference, WHR: Waist Hip Ratio, WHtR: Waist to Height Ratio, $\mathrm{W} / \mathrm{H}$ : Weight for height, Data are expressed as mean $\pm \mathrm{SD}$ and $p \leq 0.05$ is significant.

Table 2. Anthropometric characteristics in obese children with and without MetS according to pubertal status.

\begin{tabular}{|c|c|c|c|c|c|c|}
\hline Pubertal Status & & $\begin{array}{l}\text { PUBERTAL } \\
\text { n: } 97\end{array}$ & & & $\begin{array}{c}\text { PUBERTAL } \\
\mathrm{n}: 194\end{array}$ & \\
\hline $\begin{array}{l}\text { Anthropometric } \\
\text { characteristics }\end{array}$ & $\begin{array}{c}\text { Obese } \\
\text { without } \\
\text { MetS n: } 85\end{array}$ & $\begin{array}{c}\text { Obese } \\
\text { with MetS } \\
\mathrm{n}: 12\end{array}$ & $p$ & $\begin{array}{c}\text { Obesewithout } \\
\text { MetS n: } 141\end{array}$ & $\begin{array}{l}\text { Obese with } \\
\text { MetS n: } 53\end{array}$ & $p$ \\
\hline Age (years) & $9.16 \pm 2.07$ & $9.04 \pm 1.25$ & 0.93 & $13.21 \pm 1.9$ & $13.29 \pm 1.87$ & 0.795 \\
\hline Height SDS & $0.47 \pm 1.1$ & $0.32 \pm 1.35$ & 0.06 & $0.84 \pm 1.18$ & $1.01 \pm 1.41$ & 0.865 \\
\hline Weight SDS & $3.11 \pm 1.2$ & $3.51 \pm 1.8$ & 0.432 & $3.2 \pm 1.51$ & $4.2 \pm 2.27$ & 0.36 \\
\hline BMI SDS & $3.54 \pm 1.64$ & $3.36 \pm 1.41$ & 0.594 & $2.7 \pm 1.63$ & $3.01 \pm 0.59$ & 0.121 \\
\hline W/H (\%) & $143.51 \pm 17.98$ & $151.98 \pm 17.33$ & 0.005 & $139.61 \pm 14.98$ & $151.33 \pm 16.71$ & 0.01 \\
\hline WC (cm) & $97.55 \pm 12.78$ & $97.64 \pm 12.99$ & 0.885 & $82.19 \pm 7.62$ & $86.33 \pm 6.18$ & 0.066 \\
\hline WHR & $0.92 \pm 0.06$ & $0.92 \pm 0.06$ & 0.997 & $0.94 \pm 0.04$ & $0.97 \pm 0.06$ & 0.202 \\
\hline WHtR & $0.61 \pm 0.06$ & $0.62 \pm 0.07$ & 0.557 & $0.59 \pm 0.04$ & $0.62 \pm 0.04$ & 0.008 \\
\hline
\end{tabular}

SDS: Standard Deviation Scores BMI: Body mass index, WC: Waist circumference, WHR: Waist Hip Ratio, WHtR: Waist to Height Ratio, $\mathrm{W} / \mathrm{H}$ : Weight for height, Data are expressed as mean $\pm \mathrm{SD}$ and $p \leq 0.05$ is significant. 


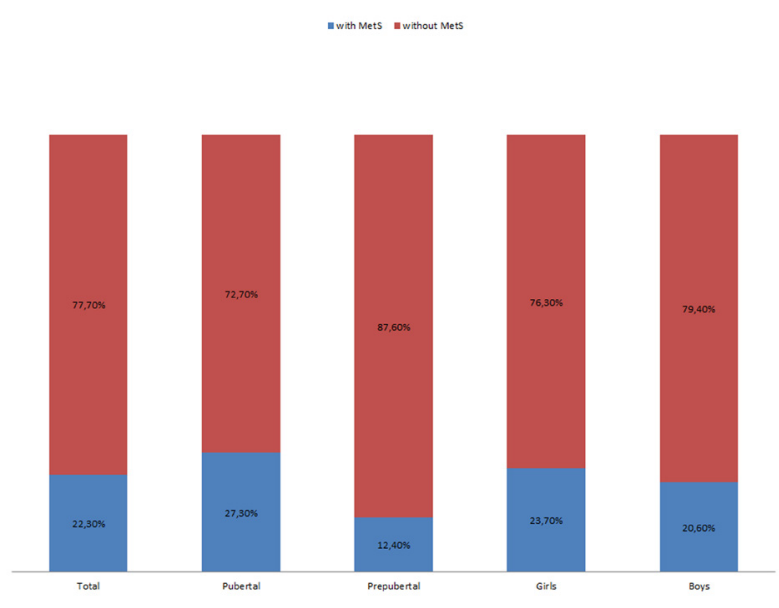

Figure1. Prevalence of MetS in obese children and adolescents. Prevalence changes according to pubertal status and gender.

The prevalence of MetS was $23.75 \%$ (38) in obese girls whereas it was $20.6 \%$ (27) in obese boys (Figure 1.). The Difference was not significant $(p=0.585)$. In obese girls, the mean age of obese girls with MetS was significantly older than obese girls without MetS $(p=0.004)$. Height SDS, BMI SDS, WC, WHR, and W/H were significantly higher in obese girls with MetS compared to obese girls without MetS $(p=0.007$, $0.04,0.013,0.021$, and 0.001 , respectively). In boys, no significant differences were found in age and anthropometric parameters between obese boys with and without MetS $(p>0.05)$ (Table 3.).

In linear logistic regression with BMI SDS, W/H, WHR, and WHtR as candidate independent variables, we found that weight for height were significant predictors of presence of MetS in all participants, despite not being strong predictors (OR:1.03, Cl95\%:1.014-1.04, $p<0.001)$. In evaluating the groups separately, we obtained similar results in pubertal (OR: 1.022, Cl95\%:1.005-1.04, $p=0.001)$ and prepubertal (OR: 1.051, Cl95\%:1.011-1.094, $p=0.013$ ) obese children and obese girls (OR: 1.043, CI95\%:1.021-1.065, $p<0.001)$ except obese boys $(p=0.332)$.

Table 4 summarizes the optimal cut-off points of the weight for height in the prediction of metabolic syndrome using ROC analysis. Specificity and sensitivity of W/H for prediction of MetS were evaluated. Among all obese children, high sensitivity of $\mathrm{W} / \mathrm{H}$ with $83.07 \%$ was reached at a value of $136.5 \%$. At this value, specificity, positive predictive value (PPV) and negative predictive value (NPV) were $40.26 \%$, $28.57 \%$, and $89.21 \%$, respectively. The optimal $\mathrm{W} / \mathrm{H}$ cutoff value for predicting MetS is $136.5 \%$ with sensitivity of $81.11 \%$ in pubertal obese children. Sensitivity, PPV, and NPV were 39.0\%, $33.33 \%$, and $84.61 \%$, respectively. Among obese girls, high sensitivity of W/H with $86.48 \%$ was reached at a value of $136.5 \%$. At this value, specificity, positive predictive value (PPV), and negative predictive value (NPV) were $48.36 \%$, $34.37 \%$, and $92.18 \%$, respectively. Among prepubertal obese children, the optimal W/H cutoff value, sensitivity, specificity, PPV and NPV are $139.5 \%, 83.33 \%, 54.11 \%, 20.4$ and 95.83, respectively.

\section{Discussion}

We investigated anthropometric markers for prediction of metabolic syndrome. It was found that weight for height is the best anthropometric marker for prediction of metabolic syndrome in the present study. Simple and easy to use markers had been investigated for prediction of MetS in both obese and non-obese children in previous studies. These studies proposed that WHtR is a simple and practical anthropometric index to identify higher metabolic risks in obese and overweight children as well as in adults [18-21]. In our study, WHtR is higher in obese children and adolescents with MetS than obese without MetS. However these differences are significant only in pre-pubertal obese children and obese girls. This result suggests that WHtR may be a marker for prediction of MetS, particularly in pre-pubertal obese children and obese girls. Similarly, it was proposed that the WHtR was a sensitive in screening for metabolic risk factors in 6-10-year-old children in one study [22]. However, logistic regression analysis revealed no associations of WHtR with MetS in the other groups as well as in pre-pubertal children and obese girls. It was surprising to find that $\mathrm{WHtR}$ was not a significant predictor of the metabolic syndrome in our study.

Waist circumference was proposed as the predictor of insulin resistance syndrome in children and adolescents [23]. Hirschler et al. demonstrated that waist circumference $>$ or $=75^{\text {th }}$. percentile could be the optimal threshold to predict metabolic syndrome in children as well [24]. In the present study, obese children with MetS had significantly higher WC than obese 
Table 3. Anthropometric characteristics in obese children with and without MetS according to gender.

\begin{tabular}{|c|c|c|c|c|c|c|}
\hline GENDER & & $\begin{array}{l}\text { GIRLS } \\
\mathrm{n}: 160\end{array}$ & & & $\begin{array}{l}\text { BOYS } \\
\mathrm{n}: 131\end{array}$ & \\
\hline $\begin{array}{l}\text { Anthropometric } \\
\text { characteristics }\end{array}$ & $\begin{array}{l}\text { Obese without } \\
\text { MetS n: } 122\end{array}$ & $\begin{array}{c}\text { Obese with MetS } \\
\mathrm{n}: 38\end{array}$ & $p$ & $\begin{array}{l}\text { Obese without } \\
\text { MetS n: } 104\end{array}$ & $\begin{array}{c}\text { Obese with MetS } \\
\text { n: } 27\end{array}$ & $p$ \\
\hline Age (years) & $11.3 \pm 2.93$ & $12.71 \pm 2.33$ & 0.04 & $11.85 \pm 2.51$ & $11.9 \pm 2.54$ & 0.672 \\
\hline Height SDS & $0.83 \pm 1.1$ & $0.21 \pm 1.27$ & 0.007 & $0.45 \pm 1.09$ & $0.78 \pm 1.47$ & 0.283 \\
\hline Weight SDS & $3.25 \pm 1.22$ & $3.6 \pm 2.02$ & 0.94 & $3.11 \pm 1.44$ & $3.72 \pm 1.76$ & 0.172 \\
\hline BMI SDS & $3.11 \pm 1.38$ & $3.37 \pm 1.51$ & 0.04 & $2.7 \pm 1.63$ & $3.01 \pm 0.59$ & 0.121 \\
\hline W/H (\%) & $140.13 \pm 16.34$ & $154.92 \pm 18.98$ & 0.001 & $144.28 \pm 17.53$ & $147.55 \pm 17.88$ & 0.392 \\
\hline WC $(\mathrm{cm})$ & $88.89 \pm 12.39$ & $95.09 \pm 13.63$ & 0.013 & $94.69 \pm 13.8$ & $93.88 \pm 11.63$ & 0.435 \\
\hline WHR & $0.91 \pm 0.06$ & $0.90 \pm 0.06$ & 0.905 & $0.95 \pm 0.05$ & $0.95 \pm 0.06$ & 0.740 \\
\hline WHtR & $0.59 \pm 0.05$ & $0.62 \pm 0.07$ & 0.021 & $0.62 \pm 0.06$ & $0.62 \pm 0.07$ & 0.906 \\
\hline
\end{tabular}

SDS: Standard Deviation Scores BMI: Body mass index, WC: Waist circumference, WHR: Waist Hip Ratio, WHtR: Waist to Height Ratio, W/H: Weight for height, Data are expressed as mean \pm SD and $p \leq 0.05$ is significant.

Table 4. Results of the ROC analyses to differentiate between obese children with and without metabolic syndrome by using weight for height percentage.

\begin{tabular}{|c|c|c|c|c|c|c|}
\hline Obese groups & $\begin{array}{l}\text { Weight for } \\
\text { Height } \\
(\%)\end{array}$ & $\begin{array}{c}\text { Sensitivity } \\
(\%)\end{array}$ & $\begin{array}{c}\text { Specificity } \\
(\%)\end{array}$ & PPV & NPV & Odds Ratio \\
\hline All children & 136.5 & $\begin{array}{c}83.07 \\
(71.31-90.85)\end{array}$ & $\begin{array}{c}40.26 \\
(33.87-46.99)\end{array}$ & $\begin{array}{c}28.57 \\
(22.36-35.66)\end{array}$ & $\begin{array}{c}89.21 \\
(81.13-94.23)\end{array}$ & $\begin{array}{c}1.032 \\
(1.012-1.052)\end{array}$ \\
\hline Pre-pubertal & 139.5 & $\begin{array}{c}83.33 \\
(50.88-97.05)\end{array}$ & $\begin{array}{c}54.11 \\
(43.00-64.85)\end{array}$ & $\begin{array}{c}20.40 \\
(10.72-24.76)\end{array}$ & $\begin{array}{c}95.83 \\
(84.57-99.27)\end{array}$ & $\begin{array}{c}1.099 \\
(1.000-1.208)\end{array}$ \\
\hline Pubertal & 136.5 & $\begin{array}{c}81.11 \\
(67.58-90.11)\end{array}$ & $\begin{array}{c}39.00 \\
(31.01-47.60)\end{array}$ & $\begin{array}{c}33.33 \\
(25.43-42.24)\end{array}$ & $\begin{array}{c}84.61 \\
(73.06-98)\end{array}$ & $\begin{array}{c}1.025 \\
(1.005-1.046)\end{array}$ \\
\hline Obese girls & 136.5 & $\begin{array}{c}86.48 \\
(71.11-95.05)\end{array}$ & $\begin{array}{c}48.36 \\
(39.28-57.54)\end{array}$ & $\begin{array}{c}34.37 \\
(25.17-44.84)\end{array}$ & $\begin{array}{c}92.18 \\
(81.99-97.08)\end{array}$ & $\begin{array}{c}1.041 \\
(1.015-1.068)\end{array}$ \\
\hline
\end{tabular}

W/H: weight for height, PPV: positive predictive values, NPV: negative predictive values, odds ratios are in $95 \%$ confidence interval (Cl). 
without MetS. When we evaluated the sample according to gender and pubertal status, only obese girls with MetS had higher WC. Maffeis et al. reported that WC and WHtR are helpful to identify metabolic risk in overweight children, but WHtR has the advantage of not requiring population-specific reference tables [19]. On the other hand, WC $\geq 90$ th percentile for age and sex is one of the features in the diagnosis of MetS. Therefore, WC was not used for regression model. Data obtained in 15 prospective studies demonstrated that the risk of cardiovascular disease increases in adults with elevation in WHR as the other anthropometric parameter [25]. In the present study, we found no association elevation in WHR with metabolic syndrome in obese children.

In this study, we determined the prevalence of MetS among obese children ages 6-16 years using the IDF definition of the metabolic syndrome. Our analyses showed that 1 in 5 obese children had the metabolic syndrome. Additionally, we found that the syndrome was more prevalent in girls than boys $(23.7 \%$ vs. $20.7 \%$ ) and pubertal obese children than prepubertal obese (27.3 vs 12.4 ). The mean overall prevalence of metabolic syndrome was 3.3\% (range 0-19.2\%) [18]. The prevalence of MetS varies based on its different definitions. Median prevalence using the IDF definition in overweight and obese children is $21.0 \%$ in Europe and $9.6 \%-21.0 \%$ in the Americas. Consistent with our results, the analysis of a systematic review made by Friend et al. revealed that metabolic syndrome prevalence was higher in older children compared with younger children [26]. Similar results were reported by Atabek et al. from Turkey [19]. With regard to the prevalence of MetS within groups categorized by gender, in contrast with our results, Friend et al. reported higher prevalence in boys compared with girls [27].

We determined that weight for height is the best anthropometric indicator predicting MetS in obese children in the present study. In assessing obese boys and girls separately, similar results could not be obtained for obese boys. In a sense, $\mathrm{W} / \mathrm{H}$ is not predicted for presence of MetS in obese boys. There is no previous study reported in the literature about this issue in obese children. A previous study has demonstrated that $\mathrm{W} / \mathrm{H}$ is the best anthropometric indicator for current nutritional status in preschool children older than one year [28]. W/H is used for the definition of overweight and obesity as well [12]. Our results demonstrated that W/H can be used for prediction of MetS in obese children. We found that optimal cut-off value of $\mathrm{W} / \mathrm{H}$ for prediction of MetS is $136.5 \%$. This value may be $139.5 \%$ in pre-pubertal obese children. This result suggests that the values of $136.5 \%$ or above for $\mathrm{W} / \mathrm{H}$ in obese children must be a sign of the presence of metabolic syndrome.

In conclusion, metabolic syndrome is more common in pubertal obese children and obese girls than pre-pubertal obese children and obese boys. Anthropometric indices should be assessed in obese children and adolescents. Waist-to-height ratio may be a indicator for the prediction of MetS, particularly in pre-pubertal children and obese girls. We conclude that weight for height may be a better marker in prediction of MetS in obese children and adolescents except obese boys. The cut-off points of $\mathrm{W} / \mathrm{H}$ were $136.5 \%$ for all obese children, pubertal obese children and obese girls and $139.5 \%$ for pre-pubertal obese children to predict MetS.

Conflict of interest statement: The authors declare no conflict of interest

\section{References}

1. D'Adamo E, Santoro N, Caprio S. Metabolic syndrome in pediatrics: old concepts revised, new concepts discussed. Curr Probl Pediatr Adolesc Health Care 2013;43:114-123.

2. Kassi E, Pervanidou P, Kaltsas G, Churousos G. Metabolic syndrome: definitions and controversies. BMC Med 2011;9:48.

3. Nguyen QM, Srinivasan SR, Xu JH, Chen W, Berenson GS. Changes in risk variables of metabolic syndrome since childhood in pre-diabetic and type 2 diabetic subjects: the Bogalusa Heart Study. Diabetes Care 2008;31:2044-2049.

4. Cornier MA, Dabelea D, Hernandez TL, et al. The metabolic syndrome. Endocr Rev 2008;29:777-822.

5. DeBoer MD, Dong L, Gurka MJ. Racial/ethnic and sex differences in the ability of metabolic syndrome criteria to predict elevations in fasting insulin levels in adolescents. J Pediatr 2011;159:975-981.

6. Moran A, Jacobs Jr DR, Steinberger J, et al. Insulin resistance during puberty: results from clamp studies in 357 children. Diabetes1999;48:2039-2044.

7. Wang Y, Rimm EB, Stampfer MJ, Willett WC, Hu FB. Comparison of abdominal adiposity and overall obesity in predicting risk of type 2 diabetes among men. Am J Clin Nutr 2005;81:555-563.

8. Brambilla $P$, Bedogni $G$, Moreno LA, et al. Cross validation of anthropometry against magnetic resonance imaging for the assessment of visceral and subcutaneous adipose tissue in children. Int $\mathrm{J}$ Obes 2006;30:23-30. 
9. Pratesi S, Paternostro F, Tani A, Sassoli C, Cappellini AC. Body mass index correlates with waist circumference in school aged Italian children. Diabetes Res Clin Pract 2012;96:7-9.

10. Elizondo-Mentemayor L, Serrano-Gonzales $M$, Ugalde-Casas PA, Bustamante-Careaga H, CuelloGarcia C. Waist-to-height: cutoff matters in predicting metabolic syndrome in Mexican children. Metab Syndr Relat Disord 2011;9:183-190.

11. Waterlow JC, Buzina R, Keller W, Lane JM, Nichaman MZ, Tanner JM. The presentation and use of height and weight data for comparing the nutritional status of groups of children under the age of 10 years. Bull World Health Organ 1977;55:489-498.

12. Zimmet P, Alberti KG, Kaufman F, et al. The metabolic syndrome in children and adolescents - an IDF consensus report. Pediatr Diabetes 2007;8:299-306.

13. Neyzi $O$, Furman $A$, Bundak R, et.al Growth references for Turkish children aged 6 to 18 years. Acta Paediatr 2006;95:1635-1641.

14. National High Blood Pressure Education Program Working Group on High Blood Pressure in Children and Adolescents: The fourth report on the diagnosis, evaluation, and treatment of high blood pressure in children and adolescents. Pediatrics 2004;114:555576.

15. Cole TJ, Bellizzi MC, Flegal KM, et.al. Establishing a standard definition for child overweight and obesity worldwide: International survey. $\mathrm{Br}$ Med J 2000;320:1240-1243.

16. Hatipoglu N, Ozturk A, Mazicioglu MM, Kurtoglu S, Seyhan S, Lokoglu F. Waist circumference percentiles for 7- to 17-year-old Turkish children and adolescents. Eur J Pediatr 2008;167:383-389.

17. Friedwald WT, Levy RI, Frederickson DS: Estimation of the concentration of low-density lipoprotein in plasma, without use of the preparative ultracentrifuge. Clin Chem 1972;18:499-500.

18. Santoro N, Amato A, Grandone A, et al. Predicting metabolic syndrome in obese children and adolescents: look, measure and ask. Obes Facts 2013;6:48-56

19. Maffeis C, Banzato C, Talamini G; Obesity Study Group of the Italian Society of Pediatric Endocrinology and Diabetology. Waist-to-height ratio, a useful index to identify high metabolic risk in overweight children. J Pediatr 2008;152:207-213.
20. Nambiar S, Truby H, Davies PS, Baxter K. Use of the waist-height ratio to predict metabolic syndrome in obese children and adolescents. J Paediatr Child Health 2013;49:281-287.

21. Hsieh SD, Yoshinaga H, Muto T. Waist-to-height ratio, a simple and practical index for assessing central fat distribution and metabolic risk in Japanese men and women. Int J Obes Relat Metab Disord 2003;27:610616.

22. Kuba VM, Leone $\mathrm{C}$, Damiani $\mathrm{D}$. Is waist-to-height ratio a useful indicator of cardio-metabolic risk in 6-10-yearold children? BMC Pediatr 2013;13:91.

23. Hirschler V, Aranda C, Calcagno Mde L, Maccalini G, Jadzinsky M. Can waist circumference identify children with the metabolic syndrome? Arch Pediatr Adolesc Med 2005;159:740-744.

24. Hirschler V, Maccallini G, Calcagno M, Aranda C, Jadzinsky M. Waist circumference identifies primary school children with metabolic syndrome abnormalities. Diabetes Technol Ther 2007;9:149-157.

25. De Koning L, Merchant AT, Poque J, Anand SS. Waist circumference and waist-to-hip ratio as predictors of cardiovascular events: meta-regression analysis of prospective studies. Eur Heart J 2007;28;850-856.

26. Friend A, Craig L, Turner S. The prevalence of metabolic syndrome in children: a systematic review of the literature. Metab Syndr Relat Disord 2013;11:7180.

27. Atabek ME, Pirgon $O$, Kurtoglu S. Prevalence of metabolic syndrome in obese Turkish children and adolescents. Diabetes Res Clin Pract 2006;72:315321.

28. Anderson MA. Comparison of anthropometric measures of nutritional status in preschool children in five developing countries. Am J Clin Nutr 1979;32:23392345. 